VELJKO R. BANDJUR ${ }^{1}$

UNIVERSITY OF BELGRADE

TEACHER TRAINING FACULTY

DUŠAN P. RISTANOVIĆ ${ }^{2}$

VLADIMIR M. STANOJEVIĆ ${ }^{3}$

UNIVERSITY OF KRAGUJEVAC

FACULTY of PEDAGOGICAL SCIENCES IN JAGOdinA

\title{
THE INFLUENCE OF A PROJECT-BASED LEARNING MODEL IN SCIENCE AND SOCIAL STUDIES ON ADOPTION OF STUDENTS' PROCEDURAL KNOWLEDGE
}

ABSTRACT. Training students to independently explore and analyze natural and social phenomena and processes is one of the more important and demanding tasks of science and social studies teaching. In order to successfully accomplish this formulated task, it is necessary for students to acquire the appropriate level of procedural knowledge, i.e. to know how to plan and conduct a research. Starting from the fact that the project work in the current reform of education in Serbia has become a mandatory teaching activity, the paper presents the results of an experimental research aimed at determining the efficiency of the project-based learning model in science and social studies in the process of acquiring procedural knowledge of students. The research was carried out on a sample of 72 students of the experimental group (three classes where the contents of the science and social studies was delivered according to the project-based learning model) and 70 students of the control group (three classes where the same contents was delivered through the usual group tasks) of the fourth grade of primary

veljko.bandjur@uf.bg.ac.rs

dusan.ristanovic@pefja.kg.ac.rs

spajki.com@gmail.com 
school. It turned out that, after the implementation of the experimental program, the achievements of the students of the experimental group improved in all three categories of procedural knowledge - the knowledge of different ways of collecting data, the knowledge of how to sort the research data, and the knowledge of how to present the research results.

KEYWORDS: project-based learning model, science and social studies, procedural knowledge, research work of students.

\section{INTRODUCTION}

Vygotsky's perception of teaching in which students should be trained how to use various "external resources" that will "alloplastically" influence the efficient construction of their knowledge (Ivić, 1992), and Dewey's notion that active acquisition of knowledge happens through the research work of students (Dewey, 1902), are embedded in the fundamental theoretical starting points of the project-based learning model in the course of science and social studies. In the light of Vygotsky's theory, the educational process and school learning constitute the basic environment for the formation of a system of scientific knowledge (scientific concepts). The essential feature that distinguishes scientific concepts from spontaneous systematics is that students during the course of teaching certain school subjects (scientific disciplines) adopt systematized scientific knowledge, relying on spontaneous concepts and cultural and historical products. The adoption of knowledge (knowing) does not imply transferring information from teachers to students, but constructing and co-constructing (Vigotski, 1983). In traditional teaching, student activities are mainly aimed at getting information, while the knowledge that develops on such occasion is often at the level of reproduction. By contrast, when students work on a project and seek a solution to the problem, they develop the understanding of key scientific principles and concepts (Blumenfeld et al, 1991). The boundaries between knowledge and the community are shifting; therefore, the structure of student activities includes skills such as identifying and understanding the problem, identifying and (re)defining goals, gathering information, interpreting the theories, designing experiments, answering questions, constructing models, observing and evaluating processes, and joint reporting of all participants on the attainment of the goals of building knowledge (Scardamalia \& Bereiter, 2003). In this 
way, postmodernist postulates of educational interpretations are also being fulfilled, meaning students are not only observers or candidates for scientific activity, but are also actively involved in the progressive discourse of science (Mirkov, 2013).

Project-based and other similar models of research work in science and social studies are focused on activities that involve self-discovery of new knowledge and improvement of the learning skills by practicing the scientific and research logic (Šefer, 2008). Since this concept of acquiring knowledge is quite different from the concept that prevails in the traditional model of teaching, it has become the subject of various researches that seek to prove its effectiveness. The results of such studies indicate that this teaching model is one of the factors of more effective learning (Geier, et al, 2008) and the potential for increasing academic achievements (Kaldi, Diamanto, Govaris, 2011; Mioduser \& Betzer, 2007). Positive effects also occur in students of lower academic achievement (Mergendoller, Maxwell, Bellisimo, 2006), although some studies have found that students were successful in planning and implementing research procedures, but the results were presented without describing their relationship or making conclusions based on complete data (Krajcik et al., 1998). In the field of developing declarative knowledge (knowledge of specific skills and algorithms) in the science and social studies, the project model proved to be more efficient than the traditional model (Ristanović, 2015). Project activities contribute to a better understanding of course content (Duncan \& Tseng, 2011) and the process of scientific research (Baumgartner \& Zabin, 2008), and positively influence the development of thinking ability (Gultekin, 2005). In examining the influence of the project-based learning model on the development of the critical thinking skills of students, a positive effect was found on the development of the ability to synthesize, evaluate, and predict with students of different levels of intellectual abilities. In addition, weaker students showed initiative, interest in team work, conscientiousness in group work (Horan, Lavaroni, Beldon, 1996) during their work on projects. Particularly positive impact on students' achievements in terms of quality of knowledge has been shown in project assignments that can be applied to different situations in real life (Barron et al., 1998).

In accordance with the appropriate theoretical knowledge, the project-based learning model in the teaching of science and social studies applied in this research has been prepared and designed so 
that it should encourage the adoption and development of different categories of knowledge, especially procedural knowledge. They imply knowledge of how to perform cognitive activities (Schunk, 2012), how to conduct research or use certain skills, and "it is often in the form of series, or sequences of steps to be followed in a certain order" (Miščević-Kadijević, 2011, p. 78). They are important for teaching because they enable the formation of concepts of a particular discipline and direct future learning and work (Mirkov, 2013). In the project-based learning model in science and social studies, procedural knowledge involves knowledge of different ways of accessing data, processing, classification, and presentation. For example, students know that the necessary information can be obtained by visiting a museum or a library, looking up information in encyclopedias or on the Internet, talking with an expert, doing field research, conducting an experiment, observing phenomena and processes, or combining these and other activities.

In addition to the need for examining procedural knowledge, they also provide the requirements in the General Standards of Achievement for the course of science and social studies (General Achievement Standards - Education Standards for the End of the First Cycle of Compulsory Education, teaching of science and social studies, 2011), as well as orientation indicators for the adoption of basic historical notions in primary school (Pešikan, 2003). From the list of indicators, the following are especially important for this research:

- When a task is given, a student can indicate how to get information about it, find the sources to learn more about a given phenomenon, knows where to look for information;

- It is really possible to get information for simpler projects using various sources (to interview people, think and find information from local history, review newspapers, catalogues, books, maps, visits various buildings, places, etc.), which means a student is trained for observation, listening, and recording of materials;

- A student knows how to use the source of historical information in a targeted and purposeful manner, for example a museum. It is advised to apply the following procedure: first to gather the necessary knowledge, so that a student can explain the problem that needs solving (the problem can be given and not self-disclosed), then the student performs field research with a 
prepared task and a clear goal of finding the answer to the initial question (Pešikan, 2003, pp. 123-124).

In addition, the collection and processing of data and the presentation of the research results also represent forms of constructing knowledge which mean that "the child enters the depth of the learning process by following the paths of the researchers, and, above all, by treating their own thought processes in the form of discovering the best strategies for solving problems which they encounter" (Šefer, 2004, p. 134).

\section{METHODS}

\section{THE AIM OF THE RESEARCH}

The aim of the research was to determine the efficiency of the project-based learning model in science and social studies in the process of acquiring procedural knowledge of students.

\section{DESCRIPTION OF EXPERIMENTAL RESEARCH}

The study was conducted in the form of a four-week parallel group experiment. The existence of cause-and-effect relationships between the project-based learning model in science and social studies (independent variable) and procedural knowledge of students (dependent variable) has been determined. After the initial measurement of the level of procedural knowledge, an experimental program was introduced to the experimental group. The sample of the content was the teaching units from the topic What was life and work like in medieval Serbia, which is studied in the fourth grade in the science and social studies course. The content of the given topic is the starting point for a more detailed study of history as a special teaching subject in the older grades of the primary school, and covers four areas: Historical sources, Chronology, Historical area, and People and events (Grahovac and Đurović, 2010).

The conditions in which group work (both experimental and control classes) was organized and realized were approximate to the way groups were formed (homogeneous according to interests and heterogeneous according to students' abilities). Also, the groups were similar in number but different according to working 
methods. Students of the experimental class realized the course content according to the project-based learning model in which the "learning of the logic of research procedures through their own projects" dominated (Šefer, 2008, p. 22), while in the control class the "usual" group work was applied.

\section{SAMPLE}

The sample of respondents consisted of three classes of the experimental and three classes of the control group of the fourth grade (age 10.3 to 11.2 years) of two primary schools in Jagodina. Students from the fourth grade were selected because it was assumed that they have stabilized their logical operations (Šefer, 2008) and that they will be able to participate in an experimental program without major issues. The research involved 142 students, 72 in the experimental classes and 70 in the control group. Equalization of groups was done based on the results of the initial testing. Based on the calculated $t$-test value $(t=0.506, d f=140)$, which is significant at $\mathrm{p}=0.614$, it has been established that there is no statistically significant difference between students of the experimental and control classes, which means that the groups are fairly uniform in the existing procedural knowledge.

\section{INSTRUMENTS}

The effects of the research experience were checked by the initial and final test of procedural knowledge. The initial test contained open and closed questions, and the final test, applied after the experimental program, contained only open questions. The test used in the research of Jasmina Šefer on the development of research thinking of younger school children (Šefer, 2008) was taken as the starting point in the construction of knowledge tests. Students were asked to determine the ways in which they would collect data in the research of the topic What was life and work like in medieval Serbia, how they would validate the data gathered by the group, and how they would present their results to others. The focus of the questions is deliberately placed on the subject, so that students will be free from the possible guidance of research procedures specific to the investigation of natural phenomena (such as conducting a study, for example). 


\section{STATISTICAL DATA PROCESSING}

In the analysis of the collected results, the following statistical procedures were used: at the level of descriptive statistics - percent, arithmetic mean (M) and standard deviation (SD); for determining differences between experimental and control group in procedural knowledge - t-test of independent samples. Data processing software used for statistical data processing was SPSS, version 17.0.

\section{RESULTS AND DISCUSSION}

\section{COLLECTING RESEARCH DATA}

Different sources of information were given to students in initial testing, and their task was to select the most appropriate way for collecting historical data.

In the category of incorrect answers only the tests with no answer given were entered, and they are relatively infrequent, $7.1 \%$ in the control and $8.3 \%$ in the experimental group. It is disturbing that only one fifth of respondents indicated the need to use more knowledge sources in the research of a particular problem, $20.4 \%$ of the total sample. The largest number of pupils opted for research from only one source of knowledge, $74.3 \%$ of the students of the control and $69.4 \%$ of the students of the experimental group. Although it is necessary to consult various sources for the reliability of the information obtained by any type of research work, it seems that this issue is not given enough attention in teaching.

In the final examination, the students of the experimental group showed great progress in relation to the students of the control group. The percentage of correct answers has increased more in the experimental (83.3\%) than in the control group (17.1\%), while in the category of partially accurate responses the situation is reversed (9.7\% in the experimental and $74.3 \%$ in the control group). The analysis of the responses shows that students of the control classes most often mention, in addition to teachers and textbooks, additional literature and the Internet as a research resource, as well as visits to specialized institutions (museums, historical archives, etc.). Contrary to them, the students of the experimental group marked museums and historical archives as the most com- 
mon ways of collecting data in the research of this topic, with the Internet and other literature in the second place. It was noticed in the answers that the teacher as the source of data necessary for research is less frequently mentioned. This result can be considered positive as it points to the tendency of students' acceptance of a change of teacher's role from a source of knowledge to someone who provides support for independent learning. The textbook is still present, but it does not prevail in students' responses.

Positive progress of the academic achievement of the students in the experimental group in the knowledge of data collection, before and after the implementation of the experimental program, can be seen in the Histogram 1:

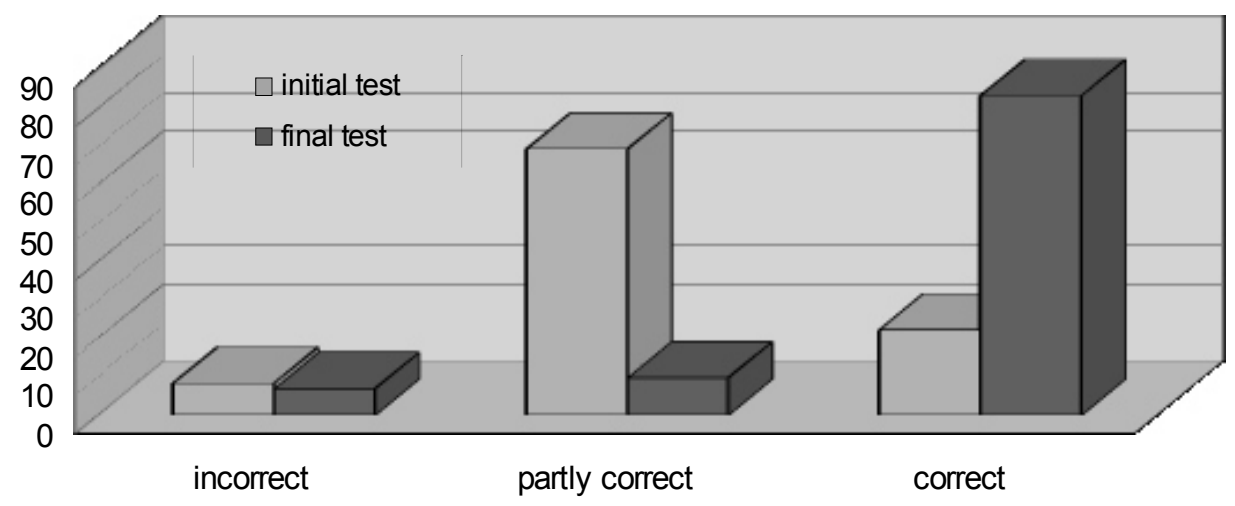

HISTOGRAM 1. ACHIEVEMENTS OF THE EXPERIMENTAL GROUP IN KNOWLEDGE OF THE METHODS OF COLLECTING RESEARCH DATA.

ХИСТОГРАМ 1: УСПЕХ СТУДЕНАТА ЕКСПЕРИМЕНТАЛНЕ ГРУПЕ У ПОЗНАВАњУ МЕТОДОЛОГИЈЕ ПРИКУПЉАҢА ПОДАТАКА

The percentage of correct answers has significantly increased as the research experience of students in the applied project-based learning model contributed to a wider choice of different sources of knowledge. In the control group, the relationship between achievements on initial and final testing of knowledge of data collection methods in the research is almost identical (Histogram 2).

\section{ARRANGING RESEARCH DATA}

Arranging the data obtained by research is an important stage in the project-based learning model in the teaching of science and social studies because it represents the path from practical observation to logical thinking. As in research activities carried out by 


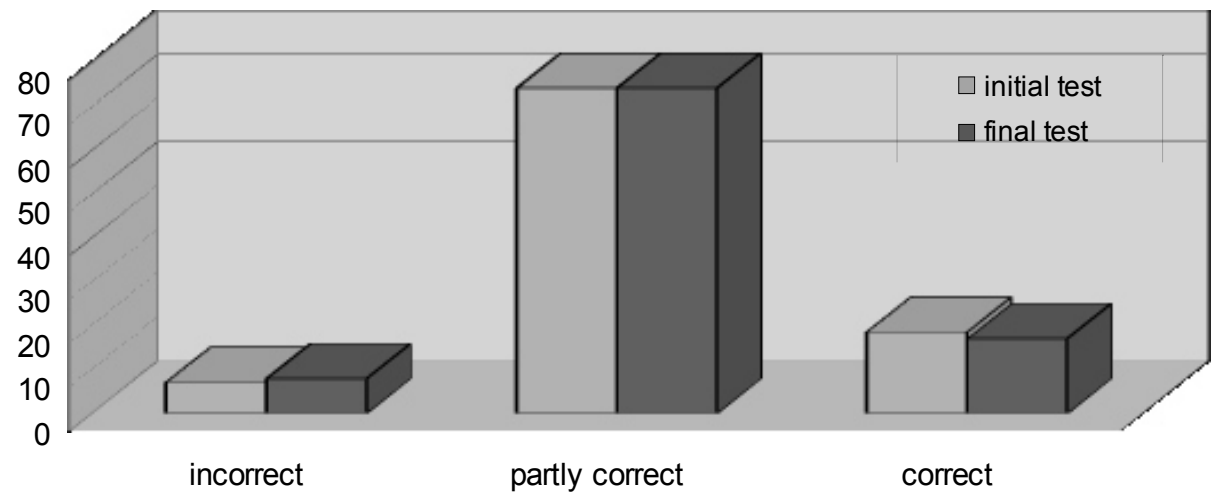

HISTOGRAM 2. ACHIEVEMENTS OF THE CONTROL GROUP IN KNOWLEDGE OF THE METHODS OF COLLECTING RESEARCH DATA

ХИСТОГРАМ 2: УСПЕХ СТУДЕНАТА КОНТРОЛНЕ ГРУПЕ У ПОЗНАВАњУ МЕТОДОЛОГИЈЕ ПРИКУПЉАҢА ПОДАТАКА

adult experts, students in this sectional model of work are trained to "determine, analyze, interpret, explain, and conceive the results and connections between the individual results obtained in the performed research" (Banđur \& Potkonjak, 1999, p. 293). Thought processes, which are particularly involved in the process of arranging data obtained by research, are:

- analysis - the interpretation of specific data and the separation of their essential characteristics (determining which issues are treated in the data obtained);

- comparison - comparing the obtained data (comparing the types of sources from which they were obtained, whether they are repeated in several different sources, etc.);

- identification - identifying the common characteristics of the individually analyzed data (whether they correspond to the topic of the research, whether it is written data, photographs, etc.);

- classification - classification into groups according to a certain similarity criterion;

- abstraction - neglecting data irrelevant to the topic of research.

In the order given, activities and processes that form the processing of the data obtained by the research should take place. Considering the importance of student training for the data processing because "it implies a logical progression of students, as 
one of the conditions for success in research work" (Šefer, 2008, p.151), students were asked to indicate ways of initial and final testing of procedural knowledge.

According to the results of the initial testing, the students had considerable difficulty in formulating the correct answers to this question. The exact answers were completely absent in both groups of subjects, with a relatively high percentage of inaccurate responses $-38.9 \%$ in the experimental and $38.6 \%$ in the control group, whereas $61.1 \%$ of the students of the experimental group and $61.4 \%$ of the control group members gave partially correct answers. At the final testing of knowledge of the data processing methods, the students of the experimental group achieved significantly better results than the students of the control group. Now, in their answers, the procedures are much clearer, using the word "compare" or "sorting out", and providing more detailed explanations. The largest number of responses is directly focused on the consideration of data quality (whether all data relates to a certain historical period, whether they relate only to Serbia or other countries, etc.).

In the repeated testing, the control group members did not give any correct answers to the raised question again. In contrast to them, $37.5 \%$ of the students of the experimental group gave accurate, detailed written answers. The proportion of partially accurate responses is relatively uniform, equaling $60 \%$ in the control and $54.2 \%$ in the experimental group. The number of incorrect responses is almost five times smaller in the experimental group (8.3\%) than in the control group (40\%). The advancement of the students of the experimental group in the knowledge of the method of compiling the data, after the realization of the project-based learning model, is also evident in Histogram 3, and the consistency of the achievements of the students in the control group on pre- and post-testing in Histogram 4.

\section{SHOWING RESEARCH RESULTS}

The final stage of the project-based learning model relates to the presentation of research results (Ristanović, 2017). As in scientific studies, the researcher, or the research team, should give a report a presentation and evaluation of the study and research. In this way they inform the public about the conducted study and the results obtained. In scientific research, reports are, as a rule, given in writing (Banđur and Potkonjak, 1999). In the process of present- 


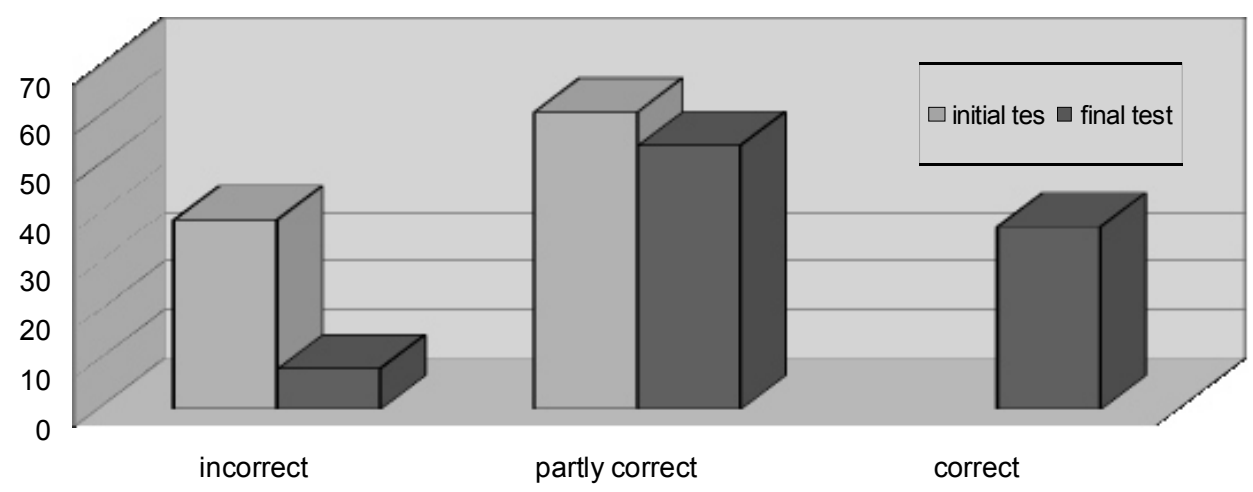

HISTOGRAM 3. THE ACHIEVEMENTS OF THE EXPERIMENTAL GROUP IN THE KNOWLEDGE OF THE METHODS OF SORTING RESEARCH DATA ХИСТОГРАМ 3: УСПЕХ СТУДЕНАТА У ЕКСПЕРИМЕНТАЛНОЈ ГРУПИ У ПОЗНАВАҢУ МЕТОДОЛОГИЈЕ СОРТИРАЬА ПОДАТАКА

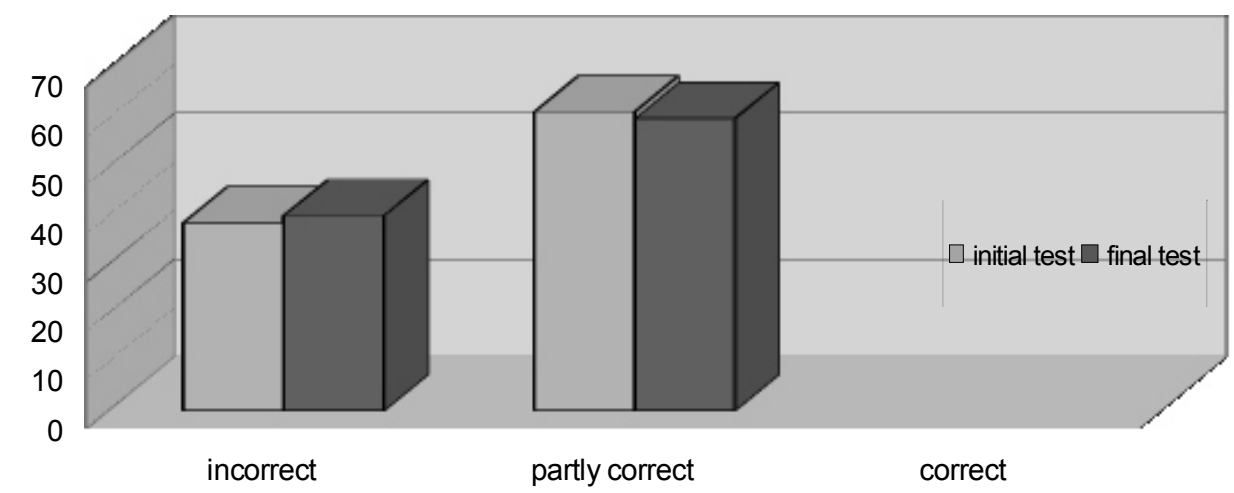

HISTOGRAM 4. ACHIEVEMENTS OF THE CONTROL GROUP IN THE KNOWLEDGE OF HOW TO SORT RESEARCH DATA

ХИСТОГРАМ 4: УСПЕХ СТУДЕНАТА У КОНТРОЛНОЈ ГРУПИ У ПОЗНАВАњУ МЕТОДОЛОГИЈЕ СОРТИРАњА ПОДАТАКА

ing the results of the research, the synthesis is especially evident the thought process of combining essential and general properties into a new whole.

In contrast to reporting in scientific research, in our case reporting is most often viewed as a variant of the oral presentation method, which "should especially be nurtured in the presentation of pupils related to different observations, educational trips, group work, excursions, visits to institutions, enterprises, and the like" (Lazarević and Banđur, 2001, p. 124). However, only the verbal communication of the research results "passivizes the listener and reduces the number of possible exposures within a limited time" 
(Šefer, 2005, p. 207), and "experience has shown that group reports, which are submitted in the synthesis phase, are often not of a satisfactory quality because they are most often read while the rest of the class is not interested nor involved" (Vilotijević, 2000, p. 188). Bearing this in mind, the applied project-based learning model is oriented towards overcoming problems of often inadequate reporting of groups in traditional teaching and on training students for better presentation of their research results.

High representation of answers classified as partially accurate (72.2\% in the experimental and $81.4 \%$ in the control group) speaks about the students' experience gained when reporting the results of group activities in the traditionally conceived teaching of science and social studies. These answers were mainly focused on one of the following three modalities:

- To a greater extent, reading the results of the research ('Read to the peers what we wrote in the notebook about the results of the task we were working on in the group');

- To a lesser extent, demonstrating and explaining explicitly the conclusions of the research ('Let's show how an experiment should be performed and explain what we have done');

- To the minimum extent, graphic communication of the results of the research ('On the cardboard, we can write the most important things that we have explored and illustrate them with charts, we can also paste some photographs or drawings').

Apart from demonstrating the views that can be conditionally interpreted with the aim of presenting the procedure, the students emphasize only the mere presentation of the results, ignoring the explanation of the goal of the activity, the process of reaching the results, and the like. However, the demonstration of an experiment is not an appropriate process in the exploration of historical themes in science and social studies. Although it is explicitly requested that the students show the process of reaching the results, the percentage of students who gave the answer is significantly lower in both groups (12.5\% in the experimental and $5.7 \%$ in the control group).

In the final examination, after the implementation of the project-based learning model, the experimental and the control groups differ greatly in the knowledge related to the ways of presenting the research results. The percentage of inaccurate responses was somewhat higher in the initial testing $(15.3 \%$ in the 
experimental to $12.9 \%$ in the control group), while it is now double the number of these responses in the control group (11.4\% in the control group and $5.6 \%$ in the experimental group). The control group still most commonly gives partially correct answers (82.9\%), while in the experimental group, only one quarter of the respondents gives partially correct answers (25\%). The biggest differences occur in the category of correct answers. After applying the project-based learning model, the percentage of students who accurately presented and explained how to present the results of the research in the experimental group was more than two thirds (69.4\%), while in the control group it remained unchanged (5.7\%).

A qualitative analysis of the responses given by students in the final test shows that there are no changes in the control group responses. Various forms of verbal reporting continue to dominate, in some cases corroborated by practical demonstrations. The experience gained by the students of the experimental group led to a change in the quality of the answer to the question of knowing how to present the results of the research. The answers categorized as accurate included both essential components: visual presentation of data (usually combined with the text), and 'methodological notes' in which the stages of the work and at least three applied procedures were presented (theme and purpose of the research, project, organization and realization of the research, data, etc.).

Shifts in the development of knowledge of how to present the results of the research among the students of the experimental and control groups, before and after the application of the project-based learning model, are also visible in Histograms 5 and 6. The lack of application of the experimental program in the control group led to almost identical achievements of the students in the initial and final test.

Differences in the achievements of the students of the experimental and control groups were also tested with the t-test (Table 1). The values of the calculated arithmetic mean values and standard deviations on the initial test of procedural knowledge are fairly uniform (in the experimental group $\mathrm{M}=2.72, \mathrm{SD}=1.21$, and in the control $\mathrm{M}=2.65, \mathrm{SD}=1.11)$. There is no statistically significant difference between the calculated mean values, $(t=0.333$, with $\mathrm{df}=140$ and $\mathrm{p}>0.05$ ), which confirms this equivalence. 


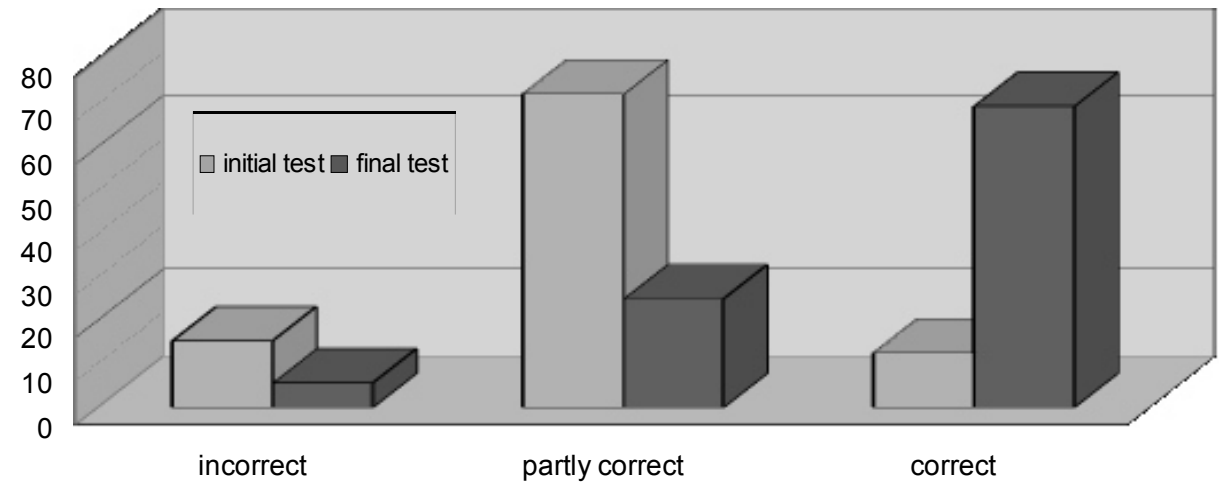

HISTOGRAM 5. THE ACHIEVEMENTS OF THE EXPERIMENTAL GROUP IN KNOWING HOW TO PRESENT RESEARCH RESULTS

ХИСТОГРАМ 5: УСПЕХ СТУДЕНАТА ЕКСПЕРИМЕНТАЛНЕ ГРУПЕ У ПОЗНАВАњУ НАЧИНА ПРЕЗЕНТОВАњА РЕЗУЛТАТА

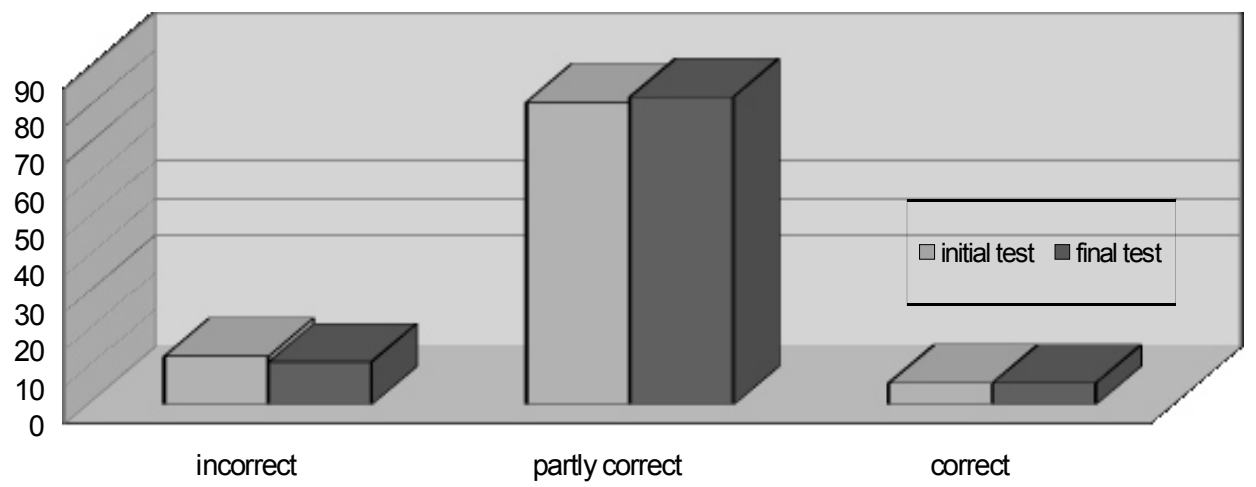

HISTOGRAM 6. ACHIEVEMENTS OF THE CONTROL GROUP IN KNOWING HOW TO PRESENT RESEARCH RESULTS

ХИСТОГРАМ 6: УСПЕХ СТУДЕНАТА КОНТРОЛНЕ ГРУПЕ У ПОЗНАВАњУ НАЧИНА ПРЕЗЕНТОВАҢА РЕЗУЛТАТА

\begin{tabular}{|c|c|c|c|c|c|c|c|}
\hline TESTING & GROUP OF RESPONDENTS & $\mathrm{N}$ & M & SD & $\mathrm{T}$ & DF & $\mathrm{P}$ \\
\hline \multirow[t]{2}{*}{ Initial } & Experimental & 72 & 2,72 & 1,21 & \multirow[t]{2}{*}{0,333} & \multirow[t]{2}{*}{140} & \multirow[t]{2}{*}{0,740} \\
\hline & Control & 70 & 2,65 & 1,11 & & & \\
\hline
\end{tabular}

TABLE 1: SIGNIFICANCE OF DIFFERENCES BETWEEN EXPERIMENTAL AND CONTROL GROUPS IN PROCEDURAL КNOWLEDGE. ТАБЕЛА 1: ЗНАЧАЈНЕ РАЗЛИКЕ У ПРОЦЕДУРАЛНОМ ЗНАҢУ ЕКСПЕРИМЕНТАЛНЕ И КОНТРОЛНЕ ГРУПЕ 
The Influence of a Project-Based Learning Model in Science And Social Studies...

\begin{tabular}{|l|l|l|l|l|l|l|l|}
\hline Final & Experimental & 72 & 4,69 & 1,56 & 0,036 & 140 & 0,000 \\
\cline { 2 - 5 } & Control & 70 & 2,62 & 1,11 & & & \\
\hline
\end{tabular}

TABLE 1: SIGNIFICANCE OF DIFFERENCES BETWEEN EXPERIMENTAL AND CONTROL GROUPS IN PROCEDURAL KNOWLEDGE. ТАБЕЛА 1: ЗНАЧАJНЕ РАЗЛИКЕ У ПРОЦЕДУРАЛНОМ ЗНАњУ ЕКСПЕРИМЕНТАЛНЕ И КОНТРОЛНЕ ГРУПЕ

The values of calculated average measures and variability from the final testing of procedural knowledge are higher in the experimental $(\mathrm{M}=4.69, \mathrm{SD}=1.56)$ than in the control group $(\mathrm{M}=2.62$, $\mathrm{SD}=1.11)$. Using the $\mathrm{t}$-test, it was found that the observed differences were statistically significant at $p<0.01(t=0.036, d f=140)$, which can be interpreted as a consequence of the application of the experimental factor. This confirmed that the project-based learning model in the teaching of science and social studies positively influences the acquisition of procedural knowledge of students.

CONCLUSION In a modern society, where one of the strategic goals of development is the creation of a 'knowledge society', the school increasingly demands greater effort in designing and implementing teaching models that will be directed at developing more functional student knowledge. The traditional model of teaching provides fast learning because it is based mostly on direct teaching - the transfer of knowledge from the teacher to the student. There is a more economical realization of the curriculum envisaged, but in most cases, their deeper understanding and application in the real social context is lacking. On the other hand, project work involves engaging thought processes and student activities that require more time, extracurricular space, and different modes of work, but research suggests that knowledge formed in this way is deeper and more durable.

For these reasons, this study examined the possibility of influencing the project-based learning model to adopt procedural knowledge. The results showed that there is a positive correlation between these two variables. In groups where classes were conducted according to the project model, the students achieved better results in all three categories of procedural knowledge collecting data, compiling data, and presenting research results. Since the experimental program included only the historical contents of science and social studies in one class, and this subject is of a highly interdisciplinary character, it would be desirable to under- 
take wider research that would cover contents from other natural and social sciences.

Nevertheless, the obtained results could be of importance to researchers who want to further study the effects of the project-based learning model in the teaching of science and social studies and other subjects, but also junior and senior class teachers - practitioners, especially if we take into consideration that the new curriculum for the first cycle of compulsory education envisages compulsory project work.

REFERENCES Banđur, V., Potkonjak, N. (1999). Metodologija pedagogije. Beograd: Savez pedagoških društava Jugoslavije.

Barron, B. J. et alii. (1998). Doing with the understanding: Lessons from research on problem and project-based learning. The Journal of the Learning Sciences, 7, 271-311.

Baumgartner, E., Zabin, Ch. J. (2008). A Case Study of Project-Based Instruction in the Ninth Grade: A Semester-Long Study of Intertidal Biodiversity. Environmental Education Research 14 (2), 97-114.

Blumenfeld, P. C. et alii. (1991). Motivating project-based learning: Sustaining the doing, supporting the learning. Educational Psychologist 26 (3\&4), 369398.

Vigotski, L. (1983). Mišljenje i govor. Beograd: Nolit.

Vilotijević, M. (2000): Didaktika 3. Beograd: Učiteljski fakultet.

Geier, R. et alii (2008). Standardized test outcomes for students engaged in inquiry-based science curricula in the context of urban reform. Journal of Research in Science Teaching 45 (8), 922-939.

Grahovac, V., Đurović, A. (ur.) (2010). Ključna znanja iz prošlosti u nastavnim predmetima Svet oko nas i Priroda i društvo kao osnova za učenje Istorije. Beograd: Zavod za vrednovanje kvaliteta obrazovanja i vaspitanja, Savez učitelja Republike Srbije.

Gultekin, M. (2005). The effect of project based learning on learning outcomes in the 5 th grade social studies course in primary education. Educational Sciences: Theory and Practice, 5 (2), 548-556.

Dewey, J. (1902). The Child and the Curriculum. Chicago: University of Chicago Press.

Duncan, R.G., Tseng, K.A. (2011). Designing project-based instruction to foster generative and mechanistic understandings in genetics. Science Education 95 (1), 21-56. 
Ivić, I. (1992). Teorije mentalnog razvoja i problem ishoda obrazovanja. Psihologija br. 3-4, 7-35.

Lazarević, Ž., Banđur, V. (2001). Metodika nastave prirode i društva. Jagodina: Učiteljski fakultet u Jagodini.

Kaldi, S., Diamanto, F., Govaris, Ch. (2011). Project-based learning in primary schools: effects on pupils' learning and attitudes. Education 3-13, 39 (1), 35-47.

Krajcik, J., et al. (1998). Inquiry in project-based science classrooms: initial attempts by middle school students. The Journal of the Learning Sciences, 7 (3\&4), 313-350.

Mergendoller, J. R., Maxwell, N. L., Bellisimo, Y. (2006). The Effectiveness of Problem-Based Instruction: A Comparative Study of Instructional Methods and Student Characteristics. Interdisciplinary Journal of Problem-Based Learning, 1(2), 49-69.

Mioduser, D., Betzer, N. (2003). The contribution of Project-based learning to high-achievers' acquisition of technological knowledge and skills, International Journal of Technology and Design Education, 18, 59-77.

Mirkov, S. (2013). Učenje - zašto i kako. Beograd: Institut za pedagoška istraživanja.

Miščević-Kadijević, G. (2011). Kooperativna nastava prirode i društva i kvalitet znanja učenika, Beograd: Učiteljski fakultet.

Opšti standardi postignuća - obrazovni standardi za kraj prvog ciklusa obaveznog obrazovanja, Priroda i društvo (2011). Beograd: Zavod za vrednovanje kvaliteta obrazovanja i vaspitanja.

Pešikan, A. (2003). Nastava i razvoj društvenih pojmova kod dece. Beograd: Zavod za udžbenike i nastavna sredstva.

Ristanović, D. (2015). Uticaj projektnog modela nastave prirode i društva na poznavanje specifičnih veština i algoritama, Uzdanica, XII (2), 71-84.

Ristanović, D. (2017). Struktura aktivnosti u projektnom modelu nastave prirode i društva, Zbornik radova Filozofskog fakulteta u Prištini, XLVII (4), 127-142.

Scardamalia, M., Bereiter, C. (2003). Knowledge Building. In: Encyclopedia of Education (2 ${ }^{\text {nd }}$ edition). New York: Macmillan Reference. pp. 1370-1373.

Schunk, D. H. (2012). Learning Theories, an Educational Perspective (6th ed.). Boston, MA: Pearson Education Inc.

Horan, C., Lavaroni, C., Beldon, P. (1996). Observation of the Tinker Tech Program students for critical thinking and social participation behaviors. Novato, CA: Buck Institute for Education. 
Šefer, J. (2004). Konstruisanje znanja kao kreativni akt i razumevanje celine. U: S. Milanović-Nahod, N. Šaranović-Božanović (ur.), Znanje i postignuće (str. 130-139). Beograd: Institut za pedagoška istraživanja.

Šefer, J. (2005). Kreativne aktivnosti u tematskoj nastavi. Beograd: Institut za pedagoška istraživanja.

Šefer, J. (2008). Evaluacija kreativnih aktivnosti u tematskoj nastavi. Beograd: Institut za pedagoška istraživanja.

ВЕљКО Р. БАНЪУР

УНИВЕРЗИТЕТ У БЕОГРАДУ

УЧИТЕЉСКИ ФАКУЛТЕТ

ДУШАН П. РИСТАНОВИЋ

ВЛАДИМИР М. СТАНОЈЕВИЋ

УНИВЕРЗИТЕТ У КРАГУЈЕВЦУ

ФАКУЛТЕТ ПЕДАГОШКИХ НАУКА У ЈАГОДИНИ

РЕЗИМЕ

\author{
УТИЦАЈ ПРОЈЕКТНОГ МОДЕЛА НАСТАВЕ ПРИРОДЕ И ДРУШТВА \\ НА УСВАЈАҢЕ ПРОЦЕДУРАЛНИХ ЗНАЬА УЧЕНИКА
}

Оспособљавање ученика да самостално истражују и анализирају природне и друштвене појаве и процесе представља један од значајнијих и захтевнијих задатака наставе природе и друштва. Да би се овако формулисан задатак успешно остварио, неопходно је да ученици стекну одговарајући ниво процедуралних знања, тј. да знају како да испланирају и спроведу истраживање. Полазећи од тога да је актуелном реформом образовања у Србији рад на пројектима постао обавезна наставна активност, у овом раду представљени су резултати експерименталног истраживања чији је циљ био да се утврди ефикасност пројектног модела наставе природе и друштва у процесу усвајања процедуралних знања ученика. Истраживање је спроведено на узорку од 72 ученика експерименталне групе (три одељења која су садржаје наставе природе и друштва реализовала по пројектном моделу) и 70 ученика контролне групе (три одељења која су исте садржаје реализовала путем уобичајених групних задатака) четвртог разреда основне школе. Показало се да су се, након завршетка примене експерименталног програма, постигнућа ученика експерименталне групе побољшала у све три категорије процедуралних знања - познавања различитих начина прикупљања података, познавања начина сређивања истражи- 
The Influence of a Project-Based Learning Model in Science And Social Studies...

вачких података и познавања начина приказивања истраживачких резултата.

КљУчнЕ РЕчи: пројектни модел наставе; настава природе и друштва; процедурална знања; истраживачки рад ученика.

Овај чланак је објављен и дистрибуира се под лиценцом Creative Commons Ауторство-Некомерцијално Међународна 4.0 (СС BY-NC 4.0 |

https://creativecommons.org/licenses/by-nc/4.0/).

This paper is published and distributed under the terms and conditions of the Creative Commons Attribution-NonCommercial International 4.0 licence (CC BY-NC 4.0 | https://creativecommons.org/licenses/by-nc/4.0/). 